\title{
Effect of Bone Morphogenetic Protein 6 (BMP6) on Chicken Granulose Cells Proliferation and Progesterone Synthesis
}

\section{-Author(s)}

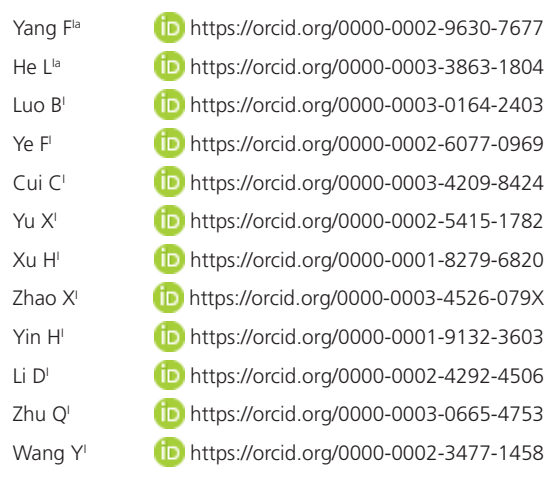

Farm Animal Genetic Resources Exploration and Innovation Key Laboratory of Sichuan Province, Sichuan Agricultural University, 211\# Huimin Road, Wenjiang District, Chengdu 611130, China.

aThese authors contributed equally to this work.

\section{-Mail Address}

Corresponding author e-mail address Yan Wang

Institute of Animal Genetics and Breeding, Farm Animal Genetic Resources

Exploration and Innovation Key Laboratory of Sichuan Province, Sichuan Agriculture University, 211\# Huimin Road, Wenjiang District, Chengdu, 611130 Sichuan Province, China.

Email: as519723614@163.com

\section{-Keywords}

Chicken; BMP6; Granulosa cells; Progesterone; FSH.

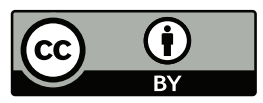

Submitted: 09/June/2018 Approved: 25/February/2019

\section{ABSTRACT}

There is increasing evidence that bone morphogenetic protein 6 (BMP6) plays critical roles in regulating various stages of ovarian follicle development in mammals. However, the mechanisms of regulation of $B M P 6$ in the chicken ovary remain unclear. In this study, mRNA and protein expression level of BMP6 in chicken ovarian follicles at different development stages were determined by qRT-PCR and western blot separately. Different concentrations of BMP6 protein and FSH were added to the culture medium, and the effects to proliferation of granulose cells were detected, further effect on expression pattern of progesterone synthesis associated genes were also analyzed by qRT-PCR and Western blotting and the secretion of progesterone was detected by ELISA. The results showed that mRNA and protein expression level of $B M P 6$ increased significantly in the follicle with the development of follicle $(p<0.05)$ and reached a peak at F1 follicle. Adding concentration of $50 \mathrm{ng} / \mathrm{ml}$ and $100 \mathrm{ng} / \mathrm{ml}$ of BMP6 protein promoted significantly the proliferation of granulosa cells $(p<0.05)$, as well as up-regulated the expression of Steroid hormone synthesis acute regulatory protein

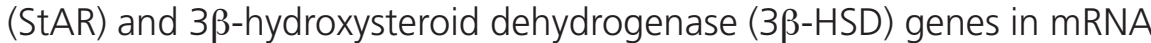
and protein level. Meanwhile, the secretion of progesterone was significantly higher in the group that added BMP6 and FSH separately than blank control group $(p<0.05)$ and reached a peak in the group that both added BMP6 and FSH. Collectively, these findings highlight that BMP6 is associated with proliferation of follicular cells and the synthesis of progesterone, which indicated that it took an important role in the follicular development of chicken.

\section{INTODUCTION}

Egg production is one of the most important economic traits of chicken (Akoğlu etal., 2018). Besides the influence of light, temperature, nutrition and other factors, it mainly depends on the growth and development of different follicles in ovarian tissues (Liu et al., 2018). Ovary development is a dynamic process controlled by several factors, which influence the reproduction of chicken. However, the mechanism of ovary development and follicle selection in chicken is still unclear.

Bone morphogenetic proteins (BMPs) belong to the transforming growth factor $\beta$ (TGF- $\beta$ ) superfamily. At present, approximately 20 BMPs family members have been identified and have been widely considered as crucial molecules involved in cell proliferation, differentiation, apoptosis, chondrogenesis, osteogenesis and embryogenesis (Chen et al., 2004; Guo \& Wu, 2012; Perrimon et al., 2012; Yan et al., 2009). BMP6 is one of the members of the BMP family thought to exert high osteoinductive potential, influencing odontogenesis (Kochanowska, et al. 2007) and bone formation (Kugimiya et al., 2005; Rickard et al., 1998). In recent 
years, BMP6 is well known to play critical roles in promoting granulose cell proliferation, follicle survival and prevent atresia in mammals (Knight \& Glister, 2006). For example, Glister et al. (Glister et al., 2005) and Miyoshi et al. (Miyoshi et al., 2007) all reported that BMP6 was expressed in oocyte and granulosa cells (GC) and its ovarian function is similar to BMP15. Shi and his colleagues found BMP6 was abundantly present in the GC of healthy tertiary follicles but not in atretic follicles. Meanwhile, they also reported that in human GCS, BMP6 could induce gene expression of follicle - stimulating hormone (FSH) receptor, inhibin/ activin beta subunits and anti-Müllerian hormone (AMH) (Shi et al., 2009). By comparison, the inhibitory effects of BMP6 on FSH responsiveness have been reported on rat (Miyoshi et al., 2007), cattle (Glister et al., 2004) and pigs (Brankin et al., 2005). In addition, in the study of sheep granulos cells, BMP6 has been shown to inhibit progesterone production, and stimulate the secretion of ovarian statin A and estradiol (Campbell et al., 2009). Subsequently, in mouse, Wang et al. (2015) also found that BMP6 could increase the rate of antral follicle muration. Therefore, it is parent that BMP6 in mammals has the capacity to modulate follicle sensitivity to gonadotropins. However, although BMP6 has been systematically studied in mammals, the functions of chicken BMP6 in the development of chicken ovaries is still unclear.

Chicken as an important economic animal, its follicle formation and development are different from mammals. It is well know that at distinct developmental stages of chicken follicles including prehierarchical follicle and hierarchical follicle, the largest preovulatory follicle (F1) is destined to be ovulated first and the second largest (F2) will follow on the subsequent day (about 24-26 h later) (Hernandez \& Bahr, 2003; Stephens \& Johnson, 2016). Similar to mammals, the follicle atresia involving the granulose cell apoptosis occurs frequently in the prehierarchial follicles $(1-8 \mathrm{~mm}$ in diameter) (Gilbert et al., 1983; Wang et al., 2007). Therefore, all of these characteristics make chicken an ideal model for deciphering the mechanisms regarding ovarian follicular selection and maturation. Thus, the objectives of this study were: (1) to determine the mRNA and protein expression levels of BMP6 in chicken ovarian follicles at different development stages; (2) to analyze the influence of different concentration of BMP6 on the mRNA expression prolife of StAR and $3 \beta-H S D$ and (3) to evaluate the effect of different concentrations of BMP6 and FSH on progesterone secretion in granulose cells.

\section{MATERIALS AND METHODS}

All experimental protocols met the Committee on Experimental Animal Management of Sichuan Agricultural University, permit number 2014-18.

\section{Animals}

Sixteen 300-day-old BHLH2 chickens were used in all the experiments in this study. BHLH2 chicken is composed of Heikang laying hens, Erlangshan mountain chicken, Luhua chicken three lines consists of the hybrid lines, with high yield characteristics. Hens were housed individually in clean laying cages and maintained on a lighting schedule of $16 \mathrm{~h}$ of light and $8 \mathrm{~h}$ of darkness on an experimental farm for poultry breeding at the Sichuan Agricultural University (Ya'an, China). During the growth period, all hens had ad libitum access to feed and water. According to the egg production recorded daily, hens with consistent laying patterns were selected and euthanized. Then, their ovaries were collected within $2 \mathrm{~h}$ of ovulation and immediately placed in ice-cold Krebs-Ringer bicarbonate buffer.

\section{Tissue extraction, RNA isolation and quantitative real-time PCR}

To examine the expression of BMP6 in growing follicles at different stage, the follicles of various sizes were removed from mature chicken ovaries ( $n=3-5$ chickens). According to their diameter, the follicles were divided into two groups: prehierarchical follicle (including whole $<2 \mathrm{~mm}$ follicles and $3-5,6-8 \mathrm{~mm}$ follicles) and hierachiacal follicle (including F1, F2, F3, F4 and F5). Then, total RNA was extracted from different size follicles using RNAiso Plus reagent (Takara, Dalian, China) according to the manufacturer's instructions. The quality of isolated RNA was determined using Nanodrop2000 (Bio-Rad, USA). The samples were adjudged pure when A260/A280 OD value was $>2$. Its integrity was assessed by $1 \%$ agarose gel electrophoresis. cDNA was synthesized using the PrimeScriptTM RT Reagent Kit with gDNA Eraser (Takara, Dalian, China) according to the manufacturer's instructions.

Four pairs of specific primers (Table 1) were used to amplify BMP6, StAR, 3 $\beta$-HSD and GAPDH, respectively. GAPDH as an internal control. The qRTPCR amplifications were performed in triplicates with $10 \mu$ reaction mixture on LightCycle96 real-time PCR instrument. The individual qRT-PCR reactions contained $5 \mu \mathrm{l}$ of SYBR premix Ex Taq ${ }^{\text {TM }}$ (Takara Biotechnology 
Table 1 - Primers used for real-time PCR

\begin{tabular}{|c|c|c|c|c|}
\hline Gene & Sequence of nucleotide $\left(5^{\prime}-3^{\prime}\right)$ & $\begin{array}{c}\text { Product } \\
\text { Length (bp) }\end{array}$ & Annealing temperature $\left({ }^{\circ} \mathrm{C}\right)$ & GenBank No. \\
\hline \multirow{2}{*}{ BMP6 } & CACGCCATCGTCCAAACTCT & \multirow{2}{*}{167} & \multirow{2}{*}{62} & \multirow{2}{*}{ XM_015275997 } \\
\hline & TGACATCCACAGGCTCTTACTACC & & & \\
\hline \multirow{2}{*}{ GAPDH } & AGGACCAGGTTGTCTCCTGT & \multirow{2}{*}{153} & \multirow{2}{*}{60} & \multirow{2}{*}{ NM_204305 } \\
\hline & CCATCAAGTCCACAACACGG & & & \\
\hline \multirow{2}{*}{ StAR } & TGCCATCTCCTACCAACA & \multirow{2}{*}{190} & \multirow{2}{*}{56} & \multirow{2}{*}{ NM_204686 } \\
\hline & СATCTCCATCTCGCTGAAG & & & \\
\hline \multirow{2}{*}{$3 \beta-H S D$} & TACTGCTGGAAGAAGATGAG & \multirow{2}{*}{206} & \multirow{2}{*}{55} & \multirow{2}{*}{ D43763 } \\
\hline & CAAGGTGTCAATGATGGAAG & & & \\
\hline
\end{tabular}

Co., Ltd, Dalian, China), $1 \mu \mathrm{l}$ cDNA (approximately 10 ng), $0.5 \mu \mathrm{l}$ of forward primer, $0.5 \mu \mathrm{l}$ of reverse primer and $3 \mu \mathrm{l}$ of RNase-free $\mathrm{H}_{2} \mathrm{O}$ (Tiangen Biotech Co., Ltd, Beijing, China) with the following procedure: $95^{\circ} \mathrm{C}$ for 2 min, 39 cycles at $95^{\circ} \mathrm{C}$ for $3 \mathrm{~s}$, annealing for $15 \mathrm{~s}$ at the primer-specific temperature $\left(62^{\circ} \mathrm{C}\right.$ for $B M P 6$ and $\mathrm{GAPDH}, 59^{\circ} \mathrm{C}$ for StAR and $3 \beta-\mathrm{HSD}$ ) and elongation for $10 \mathrm{~s}$ at $72^{\circ} \mathrm{C}$, a melting step by slow heating from $65^{\circ} \mathrm{C}$ to $95^{\circ} \mathrm{C}$ with a rate of $0.5^{\circ} \mathrm{C} / \mathrm{s}$, and continuous fluorescence measurement. The four gene mRNA expression was analyzed by the $2^{-\Delta \Delta C_{t}}$ method after testing the amplifying efficiency of the primers.

\section{Granulosa cell (GC) culture and treatments}

Primary granulosa cell cultures were collected according to the method described by AhumadaSolórzano et al. (2016) with minor modifications. In brief, the GC layer of follicles was carefully and aseptically removed from the F1 follicular wall after removing the yolk; then washed 3-4 times in PBS, and once briefly in incubation media DMEM/F12 (Hyclone, USA) with $10 \%$ fetal bovine serum (Gibco Invitrogen, USA). The granulosa cell monolayer was incubated in a protease solution containing $0.1 \%$ collagenase II (Sigma, USA) in PBS. Cells were incubated with constant agitation for $5 \mathrm{~min}$ at $37^{\circ} \mathrm{C}$ and then centrifuged at $800 \times \mathrm{g} / \mathrm{min}$ for $5 \mathrm{~min}$. The supernatant was filtered through two $20 \mu \mathrm{m}$ stainless steel mesh. After filtrate collection, centrifuged at $2000 \times \mathrm{g} / \mathrm{min}$ for $10 \mathrm{~min}$, then abandon supernatant and re-suspend in growth medium DMEM/F12 (Hyclone, Thermo Scientific) with $15 \%$ fetal bovine serum (Gibco Invitrogen, USA) and $1 \%$ antibiotic/antimycotic (ABAM; Invitrogen). Cell number and viability was determined by trypan blue exclusion. Finally, $3.0 \times 10^{5}$ viable cells per well were plated in a 6-well plate (total volume: $2 \mathrm{ml}$ ) in a humidified $5 \% \mathrm{CO}_{2}$ atmosphere incubator at $37^{\circ} \mathrm{C}$.

The cells were allowed to attach and grow (75\%$80 \%$ confluent) for $36-48 \mathrm{~h}$, and then, the media was replaced with serum-free medium containing different concentrations $(25,50$ and $100 \mathrm{ng} / \mathrm{ml})$ of BMP6 and were maintained over a period of $24 \mathrm{~h}$ interval. Control cells were grown in media without BMP6. After a $24 \mathrm{~h}$ incubation, the cells were collected for mRNA and protein isolation. Similarly, the other group of cell media was replaced with serum-free medium containing $50 \mathrm{ng} / \mathrm{ml} \mathrm{BMP6}$ and was maintained for $18 \mathrm{~h}$, and then adds $10 \mathrm{ng} / \mathrm{ml}$ FSH was maintained for $3 \mathrm{~h}$. After a $21 \mathrm{~h}$ incubation, the cell supernatant was tested by ELISA kit (Mskbio, Wuhan, China). Each treatment was tested in triplicate wells in each experiment.

\section{Cell proliferation assay}

Proliferation of cells treated with different concentration of BMP6 (0ng/ml, 25ng/ml, 50ng/ml and $100 \mathrm{ng} / \mathrm{ml}$ ) or the negative control group was determined with the Cell Counting Kit-8 (CCK-8) assay. Briefly, the cells were seeded in 96-well plates at the density of $5000-10000$ cells in $0.1 \mathrm{ml}$ per well. After culturing for $48 \mathrm{~h}, \mathrm{CCK}-8(10 \mu \mathrm{l} /$ well) was added to the medium for $4 \mathrm{~h}$ at $37^{\circ} \mathrm{C}$. The absorbance was read at $450 \mathrm{~nm}$ with a microplate reader (Thermo Fisher Scientific). All experiments were performed in triplicated.

\section{Western Blot}

For protein extraction, each different size follicles were made into powder and placed in liquid nitrogen with a precooled mortar and pestle. Protein lysates were made using Tris-Triton lysis buffer from this powder and granulosa cells, centrifuged at $14000 \times \mathrm{g} / \mathrm{min}$ in refrigerated centrifuge for $15 \mathrm{~min}$ and supernatant was collected. Protein concentrations were measured using a BCA Protein Assay Kit (BestBio, Shanghai, China). The protein lysates were then resolved by SDS-PAGE and then electro-transferred onto polyvinylidene difluoride (PVDF) membranes (Beyotime Biotech, Jiangsu, China), blocked with PBS containing $0.2 \%$ Tween-20 and $5 \%$ non-fat dry milk and incubated with the primary antibody against BMP6 (diluted 1:500, Bioss, Beijing), GAPDH (diluted 1:500, Bioss, Beijing), StAR (diluted 1:500, Bioss, Beijing) and 3 $\beta$-HSD (diluted 1:500, 
Bioss, Beijing). The membranes were washed thrice (10 min each) in Tris-buffered saline and incubated with 1:1000 diluted goat anti-rabbit HRP-tagged secondary antibody in case of BMP6, StAR, 3 $\beta$-HSD at room temperature for $1.5 \mathrm{~h}$. Finally, the membrane was incubated with a chemiluminescence $(E C L)$ reagent (Zomanbio Inc., Beijing, China), and the protein bands were visualized using a ChemiDoc XRS instrument (Bio-Rad, Inc., USA). Quantity One Software (Bio-Rad, Inc., USA) was used for densitometric analysis.

\section{Statistical analyses}

All the data were presented as mean \pm SEM. Statistical significance among the group was assessed using one-way ANOVA. The level of significance was $p<0.05$. All statistical analyses were done by using SPSS 20.0 (SPSS Inc., Chicago, IL, USA).

\section{RESULTS}

\section{BMP6 MRNA expression}

In order to investigate the expression of $B M P 6$ gene in follicles at different stages of chicken, the real-time fluorescence quantitative PCR ( $\mathrm{QRT} T \mathrm{PCR}$ ) was used for detection. As shown in Fig.1, we found that BMP6 was expressed in all different size follicles with significant variation of expression level. There was a high-level expression of BMP6 in F1 follicle, which was significantly higher than that in follicular F2, F3, F4 and F5 $(p<0.05)$, but a low-level expression in F5 follicle. Meanwhile, there was no significantly difference between F4 and F5 follicles ( $p>0.05$ ). In addition, the

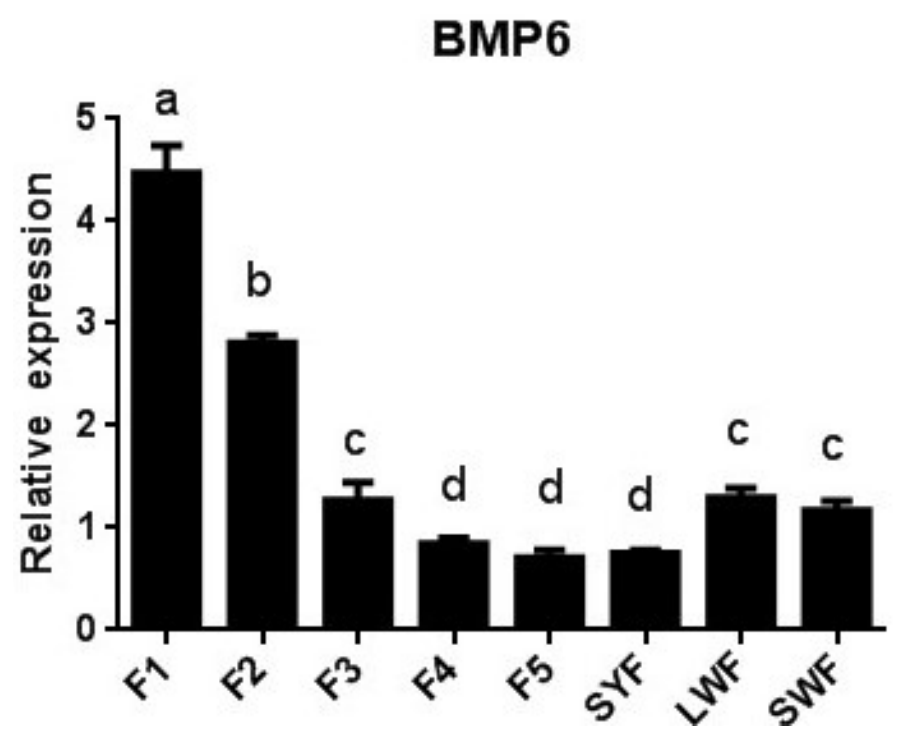

Figure 1 - Expression of BMP6 mRNA in the follicles of different stages of chicken. Data above were presented as mean $\pm \operatorname{SEM}(n=3)$, Error bars show the SEM of triplicate. Different letters represent significant $(p<0.05)$. expression level of BMP6 gene in Large White Follicles (LWF) was significantly higher than that in Small Yellow Follicles (SYF; $p<0.05$ ), but the expression level was not significantly different from Small White Follicles (SWF; p>0.05).

\section{BMP6 protein expression}

In accordance with the transcriptional data, the protein expression of BMP6 was detected in different size follicles at all levels. Western blot analysis showed that the expression of BMP6 protein was also increased with the increase of grade follicle, and the expression of BMP6 protein was high in F1 follicle, whereas it was lower in pre-follicular follicle SYF, LWF and SWF (Fig. 2).

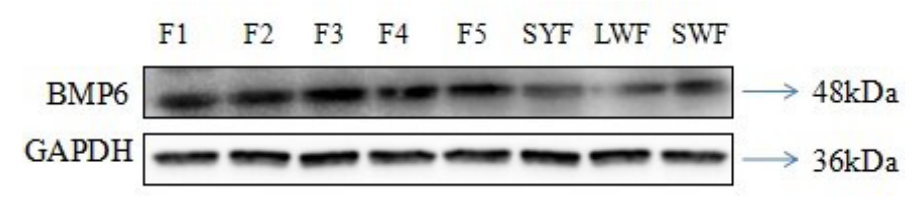

Figure 2 -Western blot analysis of BMP6 expression in different sized follicles. GAPDH was used as a loading control.

\section{Effects of BMP6 on proliferation of follicular granulosa cells in vitro}

The proliferation of granulosa cells was analyzed by CCK-8, and the results were shown in Fig 3. There was no significant change in the number of granulosa cells in the experimental group with $25 \mathrm{ng} / \mathrm{ml}$ BMP6 protein compared with the blank control group. However, the number of granulosa cells was significantly higher in the experimental group supplemented with $50 \mathrm{ng} /$ $\mathrm{ml}$ and $100 \mathrm{ng} / \mathrm{ml}$ protein compared with the blank control group (Fig 3).

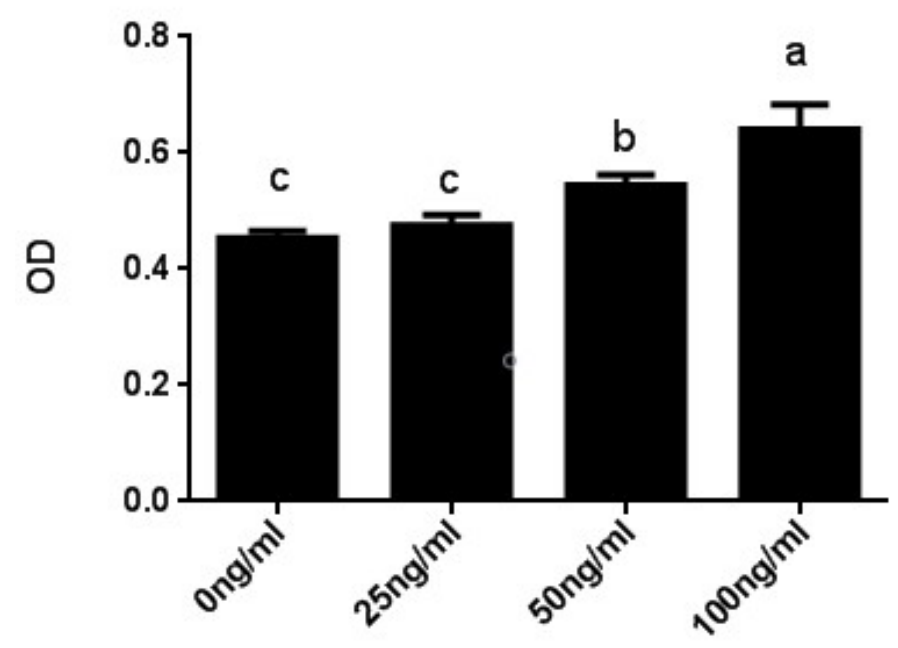

Figure 3 - Effect of different concentrations of BMP6 recombinant protein on the proliferation of granulosa cells in vitro $(p<0.05)$. The experiment was repeated 3 times, and each treatment group consisted of 6 parallel repeats. The same letters in the same column indicated that the difference between the two groups was not significant, and the differences between the two groups indicated that the difference between the two groups was significant $(p<0.05)$. 
Yang F, He L, Luo B, Ye F, Cui C, Yu X, Xu H, Zhao X, Yin H, Li D, Zhu Q, Wang Y

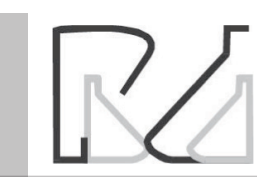

Effect of Bone Morphogenetic Protein 6 (BMP6) on Chicken Granulose Cells Proliferation and Progesterone Synthesis

\section{Expression of progesterone synthesis- related genes and proteins}

In order to study the effect of BMP6 protein on the synthesis of progesterone in chicken granulosa cells in vitro, the expression of StAR and 3 $\beta$-HSD in the different concentrations of BMP6 protein were detected by real-time quantitative $P C R$. The results showed that exogenous BMP6 protein could significantly promote the expression of StAR and $3 \beta-H S D$ genes mRNA in vitro, and the relative expression of StAR and $3 \beta-H S D$

A

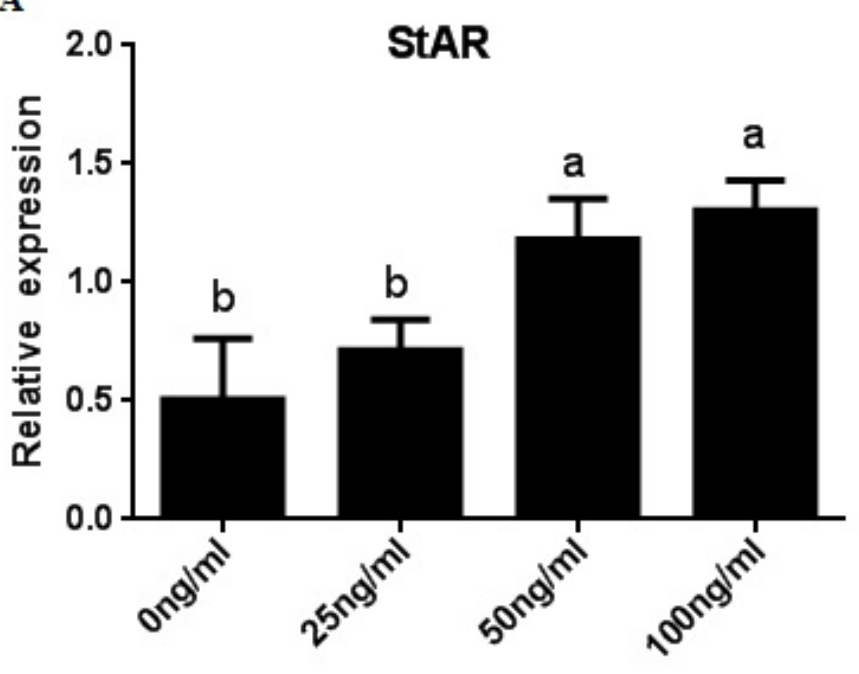

mRNA were increased with the increase of BMP6 protein content compared with blank control group, it indicated that BMP6 protein could promote the expression of StAR and $3 \beta-H S D$ mRNA in granulosa cells in a dose-dependent manner in vitro. StAR and $3 \beta$-HSD protein in three different treatment groups showed steady expression, and the expression level of StAR and 3 $\beta$-HSD protein increased with the increase of protein concentration. It was speculated that BMP6 could promote granulosa cell expression of StAR and $3 \beta$-HSD Protein (Fig 4).

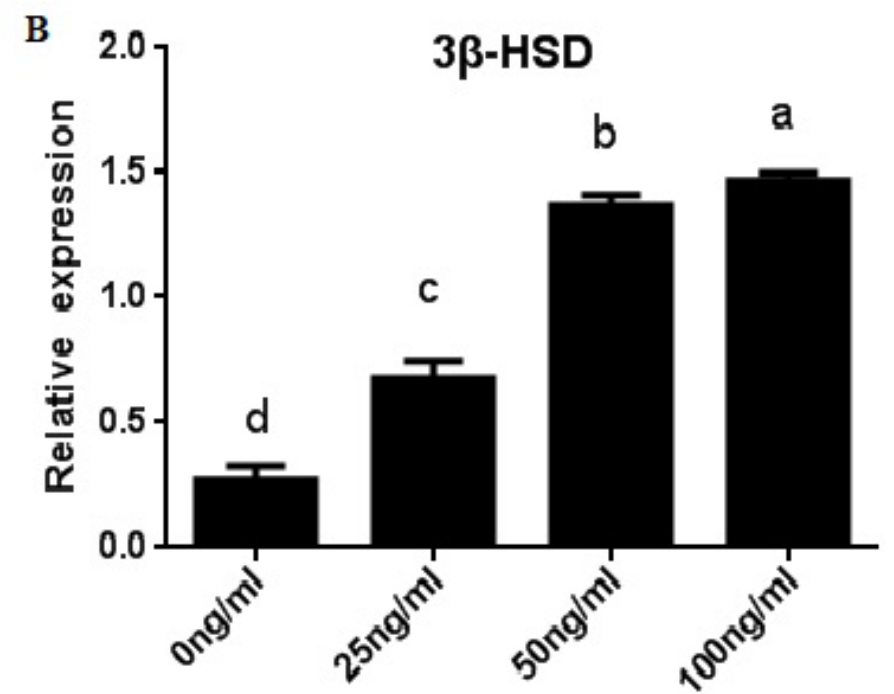

C

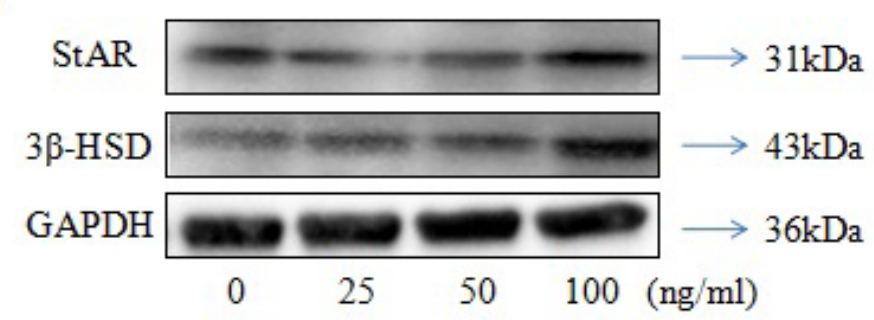

Figure 4-BMP6 protein was added to the culture medium in vitro, and the concentrations of BMP6 protein in the culture medium were 0ng / $\mathrm{ml}$ (blank control group), $25 \mathrm{ng} / \mathrm{ml}$, $50 \mathrm{ng} / \mathrm{ml}$ and $100 \mathrm{ng} / \mathrm{ml}$. After 72 hours of in vitro culture, granulosa cells were collected and the total RNA was extracted. Effects of different concentrations of BMP6 recombinant protein on StAR mRNA expression (A). The relative expression of different concentrations of BMP6 recombinant protein on 3 $\beta$-HSD mRNA. Different letters in the figure showed significant differences between the two groups ( $p<0.05)$. (B). Chicken granulosa cells cultured in serum-free medium containing 0ng/ml (blank control), $25 \mathrm{ng} / \mathrm{ml}, 50 \mathrm{ng} / \mathrm{ml}$ and $100 \mathrm{ng} /$ $\mathrm{ml} \mathrm{BMP6,} \mathrm{the} \mathrm{expression} \mathrm{of} \mathrm{StAR} \mathrm{and} \mathrm{3 \beta -HSD} \mathrm{were} \mathrm{detected} \mathrm{by} \mathrm{Western} \mathrm{Blot} \mathrm{method} \mathrm{(C).}$

Effects of BMP6 and FSH on progesterone secretion in follicular granulosa cells

In this experiment, granulosa cells from chicken were isolated and cultured with different concentrations of BMP6 protein. After adding BMP6 protein of $50 \mathrm{ng} / \mathrm{mL}$ for $18 \mathrm{~h}$, the secretion of progesterone was measured after adding $10 \mathrm{ng} / \mathrm{mL}$ FSH for $3 \mathrm{~h}$. The results showed that the secretion of progesterone in granulosa cells supplemented with BMP6 protein was significantly higher than that of BMP6 protein $(p<0.05)$, and the secretion of progesterone was significantly increased with the increase of BMP6 concentration. The progesterone secretion of granulosa cells supplemented with BMP6 protein and FSH hormone alone was significantly higher than that of blank medium $(p<0.05)$, and when BMP6 protein and FSH hormone were added, the secretion of progesterone was the highest (Fig 5).

\section{DISCUSSION}

In this study, it was found that BMP6 gene mRNA was expressed in all sized follicles, and compared with 


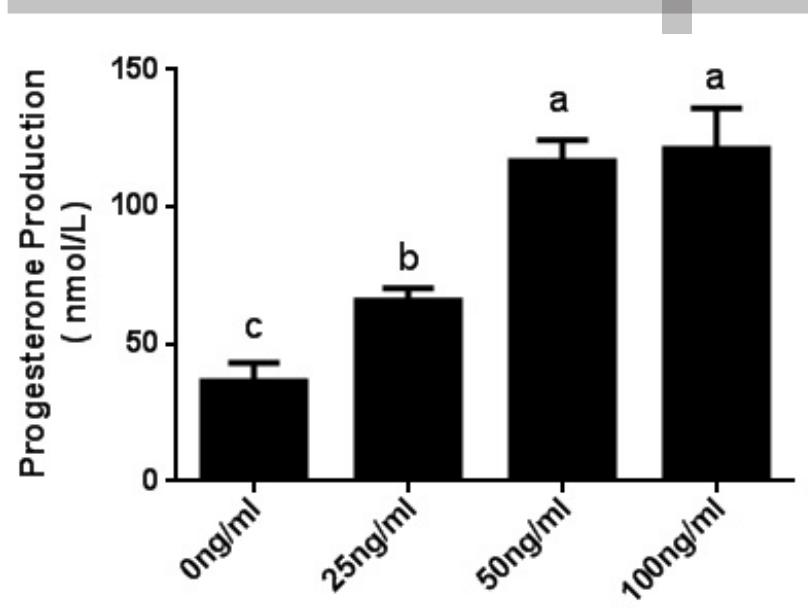

A

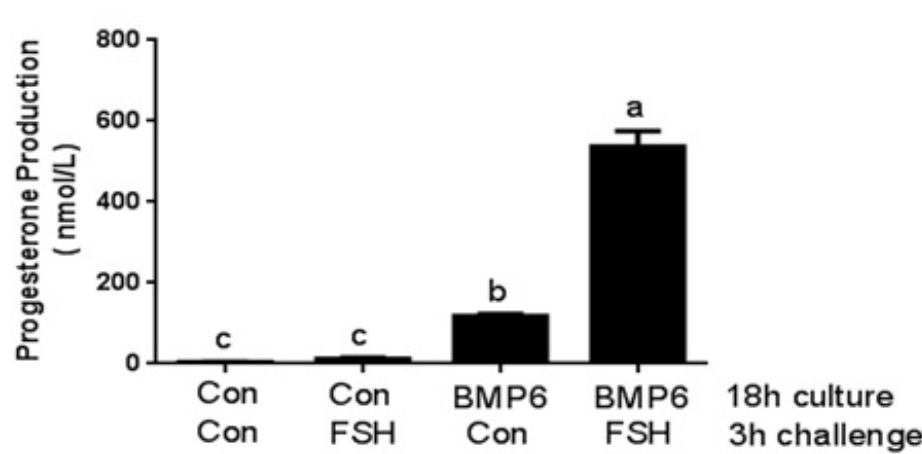

B

Figure 5 - The secretion of progesterone in follicular granulosa cells treated with different concentrations of BMP6 protein (A). Secretion of progesterone after treatment of follicular granulosa cells with BMP6 protein and FSH. After adding BMP6 protein of 50ng/mL for $18 \mathrm{~h}$, the secretion of progesterone was measured after adding $10 \mathrm{ng} / \mathrm{mL}$ FSH for $3 \mathrm{~h}$. (B). One-way ANOVA was used to determine significant differences among each value, different capital letters above the bars indicate significant differences $(P<0.05)$.

slow-growing 1-2 mm follicles, BMP6 mRNA is low expressed in SYF (6-8 $\mathrm{mm}$ follicles, the prehierarchical follicle) (Fig.1). This result is consistent with the reported by Ocon-Grove et al. (2012). However, interestingly, in our research, we found that the expression of BMP6 progressively increased with the development of follicles. This observation is different from the previous studies in avians where it is shown that a decrease in the relative expression of BMP6 as small follicles progressively increases in size (Diaz et al., 2011; Johnson et al., 2008; Ocon-Grove et al., 2012).

Moreover, previous studies have also demonstrated that BMPs have been implicated in folliculogenesis, luteinization and GC proliferation in human (Shi et al., 2012; Shi et al., 2009; Shi et al., 2011). Our result that exogenous BMP6 accelerated the proliferation of chicken granular cells in vitro is in accordance with previous reports for granular cells from cattle (Kayani et al., 2009). Brankin et al. also reported that BMP6 accelerated the proliferation of porcine granular cells (Brankin et al., 2005). However, Wang et al. found that BMP6 had no effect on morphological features during in vitro preantral follicles development (Wang et al., 2015). Similarly, exogenous BMP6 had no effect on rat granular cells proliferation (Otsuka et al., 2001). Therefore, these contradictory reports suggest that the effect to BMP6 on granular cells proliferation differs from species to species. So, the specific regulatory mechanism of BMP6 on GC proliferation is still to be further studied.

Progesterone is an important steroid hormone in female mammals. It is not only a precursor of estrogen, but also can regulate female reproductive activity with estrogen. StAR, P450scc and 3 $\beta$-HSD were the three key proteins in progesterone biosynthesis. The result from our RT-qRCR assay showed that BMP6 at a concentration of $25 \mathrm{ng} / \mathrm{mL}$ lowered the mRNA levels of the two studied genes encoding enzymes involved in steroid synthesis. Meanwhile, BMP6 at a higher concentration $(100 \mathrm{ng} / \mathrm{ml})$ enhanced the expression (on mRNA level and protein level) of StAR and 3 $\beta-H S D$. On the opposite, in cattle, previously Kayani et al. (2009) reported that StAR transcript abundance was not affected by BMP6. Similarly, in mouse, Wang et al. (2015) founded that BMP6 at high concentration suppressed the expression level of the gene for StAR and $3 \beta-H S D$. These results suggested that BMP6 may inhibit the synthesis of progesterone in mammals but promote the synthesis of progesterone in avian. Recently, some studies have also shown that BMPs play critical roles as autocrine/paracrine factors in female fertility (Otsuka, 2013). The regulation of follicle stimulating hormone (FSH) is important for the establishment of dominant follicles and subsequent ovulation. At present, little is known about the effect of FSH and BMPs on progesterone synthesis. A previous study of sheep showed that BMP4 decreased basal GC progesterone secretion and abolished FSH-stimulating action (Pierre et al., 2004). In rat, Miyoshi et al. reported that BMP6 and BMP7 both inhibited FSH- and forskolin (FSK)-induced progesterone synthesis and reduced CAMP synthesis (Miyoshi et al., 2007). Otsuka et al. also demonstrated that BMP6 inhibit the expression of StAR and progesterone synthesis (Otsuka et al., 2001). In contrast, we investigated that when added alone, both FSH and BMP6 exhibited promotion to the progesterone synthesis in avian. These data speculated that BMP6 can influence the physiological activities of ovaries by affecting the gonadal hormones pathway. 
In conclusion, BMP6 mRNA and protein were expressed in follicles at all stages of laying hens, and exogenous BMP6 protein could significantly promote the proliferation of chicken granulosa cells. BMP6 protein promoted the expression of StAR and 3 $\beta$-HSD genes in progesterone synthesis in a dose-dependent manner. The progesterone secretion of granulosa cells with $B M P 6$ protein was significantly higher than that of BMP6-free granulosa cells.

\section{ACKNOWLEDGMENTS}

The study was supported by China Agriculture Research System (CARS-41) and the Thirteenth Five Year Plan for breeding programs in Sichuan (2016NYZ0050).

\section{CONFLICTS OF INTEREST}

The authors declare that they have no competing interests.

\section{REFERENCES}

Akoğlu IT, Biyikli M, Akoğlu A, Surhan S. Determination of the quality and shelf life of sous vide cooked turkey cutlet stored at 4 and $12^{\circ} \mathrm{C}$. Revista Brasileira de Ciência Avícola 2018;20(1):1-8

Brankin V, Quinn RL, Webb R, Hunter MG. BMP-2 and BMP-6 modulate porcine theca cell function alone and co-cultured with granulosa cells. Domestic Animal Endocrinology 2005;29:593-604.

Campbell BK, Kendall NR, Baird DT. Effect of direct ovarian infusion of bone morphogenetic protein 6 (BMP6) on ovarian function in sheep. Biology of Reproduction 2009;81(5):1016-23.

Chen D, Zhao M, Mundy GR. Bone morphogenetic proteins. Growth Fators 2004;22(4):233-241.

Diaz FJ, Anthony K, Halfhill AN. Early avian follicular development is characterized by changes in transcripts involved in steroidogenesis, paracrine signaling and transcription. Molecular Reproduction and Development 2011;78:212-223.

Gibert AB, Perry MM, Waddington D, Hardie MA. Role of atresia in establishing the follicular hierarchy in the ovary of the domestic hen (Gallus domesticus). Journal of Reproduction and Fertility 1983;69:221227.

Glister C, Kemp CF, Knight PG. Bone morphogenetic protein (BMP) ligands and receptors in bovine ovarian follicle cells:actions of BMP-4, -6 and -7 on granulosa cells and differential modulation of Smad-1 phosphorylation by follistatin. Reproduction 2004;127:239-254.

Glister C, Richards SL, Knight PG. Bone morphogenetic proteins (BMP)$4,-6$ and -7 protently suppress basal and luteinizing hormoneinduced androgen production by bovine theca interna cells in primary culture:could ovarian hyperandrogenic dysfunction be caused by defect in thecal BMP signaling? Endocrinology 2005;146:1883-1892.

Guo J, Wu G. The signaling and functions of heterodimeric bone morphogenetic proteins. Cytokine \& Growth Factor Reviews 2012;23:61-67.
Hernandez AG, Bahr JM. Role of FSH and epidermal growth factor (EGF) in the initiation of steroidogenesis in granulosa cells associated with follicular selection in chicken ovaries. Reproduction 2003;125:683-691.

Johnson PA, Kent TR, Urick ME, Giles JR. Expression and regulation of anti-müllerian hormone in an oviparous species, the hen. Biology of reproduction 2008;78:13-19.

Kayani AR, Glister C, Knight PG. Evidence for an inhibitory role of bone morphogenetic proteins in the follicular-luteal transition in cattle. Reproduction 2009;131(1):67-78.

Knight PG, Glister C. TGF- $\beta$ superfamily members and ovarian follicle development. Reproduction 2006;132:191-206.

Kochanowska I, Chaberek S, Wojtowicz A, Marcyński B, Włodarski K, Dytko $M$, et al. Expression of genes for bone morphogenetic proteins BMP2, BMP6 and BMP6 in various parts of the human skeleton. BMC Muschuloskeletal Disorders 2007;27(8):128.

Kugimiya F, Kawaguchi H, Kamekura S, Chikuda H, Ohba S, Yano F, et al. Involvement of endogenous bone morphogenetic protein BMP2 and BMP6 in bone formation. The Journal of Biological Chemistry 2005;280(42):35704-35712.

Liu D, Qin N, Niu X, Zhang F, Sun X, Xu R. Characteristic of Spatio-temporal expression of PAPPA2 gene in the developing follicles of chickens. Journal of Jilin Agricultural University 2018;40(1):110-114.

Miyoshi T, Otsuka F, Inagaki K, Otani H, Takeda M, Suzuki J, et al. Differential regulation of steroidogenesis by bone morphogenetic proteins in granulosa cells:involvement of extracellularly regulated kinase signaling and oocyte actions in follicle-stimulating hormone-induced estrogen production. Endocrinology 2007;148:337-345.

Ocon-Grove OM, Poole DH, Johnson AL. Bone morphogenetic protein 6 promotes FSH receptor and anti-müllerian hormone mRNA expression in granulomas cells from hen prehierarchal follicles. Reproduction 2012;143:825-833.

Otsuka F. Multifunctinal bone morphogenetic protein system in endocrinology. Acta Medica Okayama 2013:67(2):75-86.

Otsuka F, Moore RK, Shimasaki S. Bioglogical function and cellular mechanism of bone morphogenetic protein 6 in the ovary. The Journal of Biological Chemistry 2001;276(35):32889-32895.

Perrimon N, Pitsouli C, Shilo BZ. Signaling mechanisms controlling cell fate and embryonic patterning. Cold Spring Harbor Perspectives Biology 2012;4(8):a005975

Pierre A, Pisselet C, Dupont J, Mandon-Pépin B, Monniaux D, Monget P, et al. Molecular basis of bone morphgenetic protein- 4 inhibitory action on progesterone secretion by ovine granulosa cells. Journal of Molecular Endocrinology 2004;33(3):805-17.

Rickard DJ, Hofbauer LC, Bonde SK, Gori F, Spelsberg TC, Riggs BL. Bone morphogenetic protein- 6 production in human osteoblastic cell lines. The Journal of Clinical Investigation 1998;101(2):413-422.

Shi J, Yoshino O, Osuga Y, Akiyama I, Harada M, Koga K, et al. Growth differentiation factor 3 is induced by bone morphogenetic protein 6 (BMP-6) and BMP-7 and increase luteinizing hormone receptor messenger RNA expression in human granulosa cells. Fertility and Sterility 2012;97(4):979-983

Shi J, Yohsino O, Osuga Y, Koga K, Hirota Y, Hirata T, et al. Bone morphogenetic protein- 6 stimulates gene expression of folliclestimulating hormone receptor, inhibin/activin beta subunits, and antiMüllerian hormone in human granulosa cells. Fertility and Sterility 2009;92(5):1794-1798. 
Shi J, Yoshino O, Osuga Y, Koga K, Hirota Y, Nose E, et al. Bone morphogenetic protein-2 (BMP-2) increases gene expression of FSH receptor and aromatase and decreases gene expression of $\mathrm{LH}$ receptor and StAR in human granulosa cells. American Journal of Reproductive Immunology 2011;65(4):421-427.

Stephens CS, Johnson PA. Bone morphogenetic protein 15 may promote follicle selection in the hen. General and Comparative Endocrinology 2016;235:170-176.

Wang X, Su L, Pan X, Yao J, Li Z, Wang X, et al. Effect of BMP-6 on development and maturation of mouse preantral follicles in vitro. Biotechnology Biotechnological Equipment 2015;29(2):336-344.
Wang Y, Li J, Wang CY, Yan KA, Leung FC. Epidermal growth factor (EGF) receptor ligands in the chicken ovary:I. Evidence for Heparin-Binding EGF-Like growth factor (HB-EGF) as a potential oocyte-derived signal to control granulose cell proliferation and HB-EGF and kit ligand expression. Endocrinology 2007;148(7):3426-3440.

Yan J, Yang S, Zhang J, Zhai C, Zhu T. BMP6 attenuates oxidant injury in HK-2 cells via Smad-dependent HO-1 induction. Free Radical Biology \& Medicine 2009;46:1275-1282. 